\title{
Deterrence Effects of Korean Antitrust Enforcement on Producer Prices and Profit Margins*
}

\author{
Robert M. Feinberg, American University, Washington, DC \\ and \\ Minsoo Park, Sungkyunkwan University and CERK
}

July 2014

\section{Introduction}

Antitrust enforcement is by now well-established in Korea, yet there has been little study of its effectiveness. Connor (2008), however, noted that "the Korean FTC has the best record of anti-cartel enforcement in Asia" and Jeong and Masson (1990) found evidence of market structure impacts on industry performance in Korea. In this paper we examine several datasets to investigate whether antitrust enforcement in Korea, especially anti-cartel activity, has had desirable price-limiting impacts over the past couple of decades.

We focus on two types of improper concerted actions, price fixing and big rigging. These are the main types of violation among Korean antitrust cases as seen in Table 1. We use panel data methods which allow us the opportunity to compare the behavior of firms and industries subjected to antitrust investigation to others and to examine the responses of these firms and industries themselves following the cases.

*We acknowledge financial support from CERK (Center for Economic Research of Korea), and thank Hanhyung Pyo and Joowon Kim for excellent research assistance. An earlier version of this paper was presented at a conference on Regulatory Reform, Innovation and the Future of the Korean Economy at Sungkyunkwan University in May 2014. 
Table 1. Korean Antitrust Cases by Type of Violation

\begin{tabular}{|c|c|c|c|c|c|c|c|c|c|}
\hline Year & $\begin{array}{c}\text { Price } \\
\text { Fixing }\end{array}$ & $\begin{array}{c}\text { Terms of } \\
\text { Transaction }\end{array}$ & $\begin{array}{l}\text { Production } \\
\text { restriction }\end{array}$ & $\begin{array}{l}\text { Allocation } \\
\text { of region }\end{array}$ & $\begin{array}{c}\text { Restriction } \\
\text { of } \\
\text { specification }\end{array}$ & $\begin{array}{c}\text { Establishment } \\
\text { of joint } \\
\text { company }\end{array}$ & $\begin{array}{c}\text { Interfering } \\
\text { with } \\
\text { business }\end{array}$ & $\begin{array}{c}\text { Bid } \\
\text { rigging }\end{array}$ & Total \\
\hline '81 '95 & 100 & 8 & 7 & 14 & 1 & 3 & 7 & 0 & 140 \\
\hline 1996 & 27 & 1 & 0 & 3 & 0 & 2 & 3 & 0 & 36 \\
\hline 1997 & 14 & 1 & 1 & 3 & 0 & 1 & 2 & 0 & 22 \\
\hline 1998 & 33 & 0 & 0 & 2 & 0 & 0 & 2 & 0 & 37 \\
\hline 1999 & 29 & 0 & 0 & 0 & 0 & 0 & 5 & 0 & 34 \\
\hline 2000 & 37 & 3 & 2 & 2 & 0 & 3 & 0 & 0 & 47 \\
\hline 2001 & 32 & 3 & 0 & 4 & 0 & 2 & 2 & 0 & 43 \\
\hline 2002 & 31 & 2 & 1 & 5 & 1 & 5 & 2 & 0 & 47 \\
\hline 2003 & 16 & 2 & 1 & 1 & 0 & 0 & 3 & 0 & 23 \\
\hline 2004 & 28 & 1 & 1 & 1 & 1 & 1 & 2 & 0 & 35 \\
\hline 2005 & 38 & 0 & 0 & 5 & 0 & 2 & 1 & 0 & 46 \\
\hline 2006 & 37 & 0 & 2 & 1 & 1 & 2 & 2 & 0 & 45 \\
\hline 2007 & 33 & 1 & 1 & 4 & 0 & 0 & 5 & 0 & 44 \\
\hline 2008 & 52 & 0 & 0 & 7 & 0 & 3 & 3 & 0 & 65 \\
\hline 2009 & 29 & 3 & 1 & 4 & 0 & 2 & 1 & 21 & 61 \\
\hline 2011 & 27 & 4 & 0 & 3 & 0 & 1 & 2 & 34 & 71 \\
\hline 2012 & 17 & 0 & 3 & 0 & 0 & 3 & 2 & 16 & 41 \\
\hline 2013 & 18 & 1 & 4 & 3 & 0 & 1 & 3 & 16 & 46 \\
\hline Total & 621 & 30 & 25 & 65 & 4 & 33 & 50 & 117 & 945 \\
\hline Ratio & $65.7 \%$ & $3.2 \%$ & $2.6 \%$ & $6.9 \%$ & $0.4 \%$ & $3.5 \%$ & $5.3 \%$ & $12.4 \%$ & $100 \%$ \\
\hline
\end{tabular}

\section{A Brief History of Anti-cartel Enforcement in Korea}

Korean antitrust law (the Monopoly Regulation and Fair Trade Act or in short "Fair Trade Act") was enacted in 1981 and the Fair Trade Commission (KFTC) was established in conformity with the law. At first the KFTC was a part of the Economic Planning Board (EPB), 
But soon the KFTC became an independent administrative organization separate from the EPB. In the initial period of the Act, firms were only required to register with the EPB when they coordinated their behavior in terms of price, sales, and territory of business with other firms. The EPB could refuse registration when there was concern about restriction on competition but registration was accepted if the inevitability of collusive behavior for survival of the firms was acknowledged.

The KFTC became very active in investigating cartels after 1986 when the Fair Trade Act was amended to introduce a positive system where cartels are illegal in principle. Mutual consent with no evidence of actual practice became sufficient to build a cartel case starting in 1992. In 1997, Korea became one of the first countries in Asia to introduce the leniency program to encourage cartel members to inform on their cohorts. The Act allows the KFTC to reduce surcharge penalties on such early informers. When it was introduced, the rate of leniency for the first informant was 75 to $100 \%$ of surcharge before the initiation of investigation. Since full immunity began to be guaranteed in 2005 , the cartel cases with leniency have been growing, as can be seen in Figure 1. Choi (2011) documents, as well, the impact on cartel duration and fines associated with the strengthened leniency program. ${ }^{1}$

\footnotetext{
${ }^{1}$ Brenner (2009) had earlier documented similar impacts from the EU leniency program, and Miller (2009) did the same for US policy.
} 
$<$ Figure 1> Number of cartel cases with Leniency

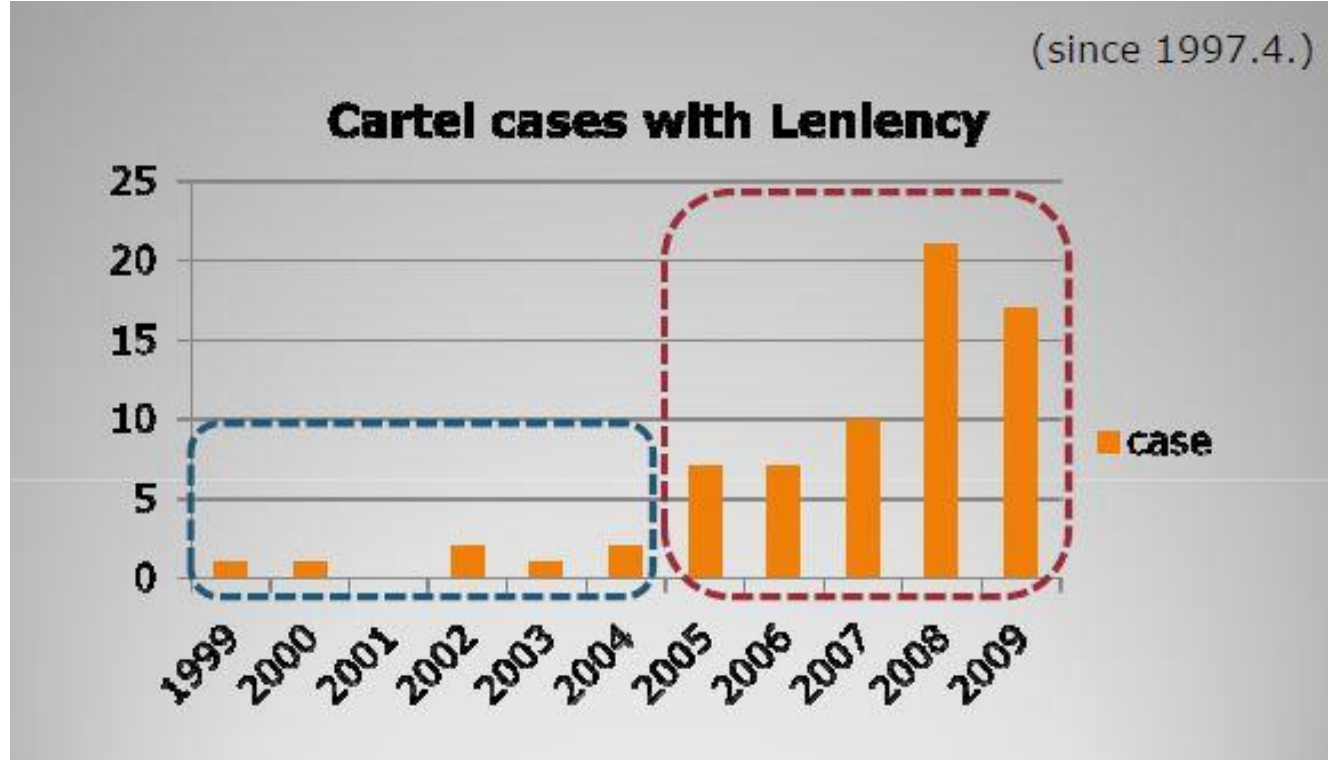

Source: http://eng.ftc.go.kr/files/static/Quick_Link/Leniency\%20Program\%20of\%20Korea.pdf

Initially the Korea FTC could only order firms to correct their violations. Fines against cartels were introduced in the 1986 amendment and the first case of cartel fines occurred in 1988. The maximum charge was $1 \%$ of the volume of affected commerce during the period of cartels in 1986 and it was raised to $5 \%$ in 1994 and to $10 \%$ in 2004. Criminal penalties for cartels now include prison terms of up to three years.

\section{Previous Literature}

Before addressing the literature on effects of antitrust enforcement, first consider the mechanisms by which this enforcement can influence company pricing behavior. One $-\mathrm{a}$ regime effect - reflects a changed perception by all firms in an economy of the increased probability of detection and conviction and/or the financial sanctions likely to be faced if convicted of antitrust violations. This effect, which could be due to legislative action or 
significant changes in case-filing and sentencing activity, would likely lead to lower prices across the board; Feinberg (1980) and Block et al. (1981) present simple models demonstrating this effect.

In terms of purely case-specific effects we can identify both strategic and deterrent effects. A strategic effect could be seen as a cartel response to an ongoing investigation aimed at either reducing the likelihood of a case being filed or the financial damages resulting; it also could be viewed - in the current regime of amnesty/leniency programs - as price-reductions occurring due to cartel members defecting leading to a case filing (hence a possible reverse causality here - with cartel collapse leading both to a price decline and a case being filed). ${ }^{2}$

Deterrent effects of a specific case on pricing of the firms involved are longer-lasting impacts continuing after the resolution of a case. However, these are only likely to occur (at least for a significant period of time) if an existing case outcome raises the chance of future cartel detection by the authorities (or weakens potential cartel members' incentives to participate) or increases the sanctions faced if detected/convicted. If a case against some firms in an industry changes the expectations by others in the industry of greater antitrust scrutiny, we may find effects on their pricing behavior as well.

\footnotetext{
${ }^{2}$ There has been some theoretical research suggesting a possible perverse impact of leniency/amnesty programs which may enhance the credibility of punishment threats and therefore help to strengthen a cartel. See, for example, Motta and Polo (2003) and Harrington (2008).
} 
A variety of approaches have been used to examine the effects of antitrust (often simply called "competition policy"). ${ }^{3}$ Survey approaches by Beckenstein and Gabel (1982) - of American antitrust lawyers, Feinberg (1985) - of EU antitrust lawyers, Gordon and Squires (2008) - of UK competition lawyers and companies, and Hulschelrath et al. (2011) - of Swiss antitrust lawyers and firms affected by enforcement, have found support for the view that deterrence can be achieved, especially if sanctions are increased.

Research on US, European and German antitrust has found some evidence of deterrence effects of price-fixing investigations, with effects declining over time. Feinberg (1980) presented a simple theoretical model suggesting that past enforcement for a firm or in an industry would lead to subsequent pricing effects, assuming that higher prices bring more antitrust scrutiny and that past antitrust cases increase the likelihood of high prices being confronted by a new antitrust case; in a cross-section of 288 US firms, regression analysis finds that past cases lead to a lower Lerner Index $[(\mathrm{p}-\mathrm{mc}) / \mathrm{p}]$. Feinberg (1986) examined effects of both German and EU antitrust cases on both producer price indexes and profit margins in that country - evidence is found of relatively short-term deterrence effects but little long-term impact. Sproul (1993), however, found no significant impact of U.S. antitrust enforcement on subsequent prices.

In studies of a particular industry, Block et al. (1981) found evidence of negative impacts on markups above cost in the US white bread industry of increased antitrust enforcement resources, while Feinberg (1984) looks at producer price index movements in 5 industries subject

\footnotetext{
${ }^{3}$ We focus here on studies of effects on firm behavior and performance. Van Sinderen and Kemp (2008) simulate impacts of Dutch competition policy on consumer surplus, but also examine impacts on economy-wide production and employment. Others have examined broader societal implications of antitrust regimes - see, for example, Petersen (2013).
} 
to US Antitrust investigations, finding significant price reductions due to the case filings in 4 of these. Clarke and Evenett (2003) studied the effects of global differences in antitrust regimes on import values during the international vitamin cartel of the 1990s, finding evidence of greater consumer harm in countries with weaker antitrust enforcement measures. Similarly, Sabbatini (2008) looks at impacts of Italian Competition Authority involvement in the baby formula and fresh milk markets during the 2000s, finding a mixed pattern of price effects.

In several papers, Connor $(2004,2006,2008)$ has found evidence of significant financial sanctions imposed by the US and foreign antitrust authorities, but the limited degree to which these offset cartel overcharges. He argues that the deterrence effect of these sanctions will be limited unless fines are increased as a share of affected commerce and the overcharges themselves. However in his work, as in much of the empirical literature on antitrust deterrence, what is actually examined is the magnitudes of fines (and sometimes jail sentences) and civil damages imposed - assuming (possibly correctly) that increasing penalties will translate into more deterrence; but, it has also been suggested that probability of detection and conviction and not magnitude of penalties is what will deter cartel activity the most. At best, however, this is quite an indirect approach to deterrence, and what seems preferable (though often more difficult due to data limitations) is the more direct look at cartel occurrence or price effects due to antitrust enforcement.

Bergman (2008) discusses a variety of methodologies which have been used recently in assessing competition policies, noting a small number of econometric studies of price effects of mergers and a larger number of such studies of cartel effects on prices, but little in the way of 
econometric analysis of competition authority anti-cartel impacts. Connor (2007) exhaustively surveys these studies of cartel price effects, finding a median of 770 average price effects estimated in the studies to be 25\%. Werden (2008) finds this number to be somewhat high and takes as a more reasonable figure a 10\% price effect for US criminal cartel prosecutions. But, again, these are estimates of the effects of the cartels detected - whether the antitrust case reversed entirely the price effects on consumers is merely assumed, not shown. Clearly though, quantifying the magnitude of consumer gain from anti-cartel efforts -- though most likely substantial - is quite difficult.

Two types of deterrence studies can be conducted: (1) looking only at firms/products involved and testing for impacts; (2) looking across all firms/products and testing for differences between the two groups - in this study we attempt to do both. This allows us both to compare investigated companies and industries with others and to observe effects over time within those investigated.

\section{Theoretical Motivation and Econometric Methodology}

Early work, such as Feinberg (1980) and Block et al. (1981) assumed that enhanced antitrust enforcement would affect industry prices through increasing the probability of future cartel detection, but there was no discussion of the timing of these effects or of the dynamics of cartel activity. More recent studies have focused on how the presence of an antitrust agency (and leniency programs) influences incentives towards collusion and defection, with implications for the cartel's optimal price path. ${ }^{4}$

\footnotetext{
${ }^{4}$ See, for example, Harrington (2005).
} 
Harrington (2004) discusses how typical methods of calculating cartel damages after detection by the authorities may limit price declines during the period of litigation; nevertheless, there is a decline in price suggesting that some of the pro-competition impact of antitrust enforcement will be of the "strategic" nature mentioned above. ${ }^{5}$ This implies that the short-run deterrent impact of Korean enforcement estimated below - one-year beyond the resolution of the case - may be somewhat biased down (as some of the price reduction has already occurred). Bolotova et al. (2008) examines the US citric acid and lysine conspiracies of the 1990s; while their focus is on reduced variance in pricing as a potential screen for identifying cartels, they do find mean prices to fall post-cartel

Longer-term, however, firms convicted of antitrust violations would need to anticipate an extended period of enhanced scrutiny by the authorities in order that a case would lead to lasting pro-competitive impacts. Whether this is in fact what has occurred in Korea is an empirical question and what we now turn to.

Given that the first anti-cartel fines in Korea were issued only in the late 1980s, it would not be expected that deterrence would be observed for at least several years beyond that. We start our analysis in 1990 (through 2013), and undertake two closely-related reduced-form econometric studies. First, we explain the impact of antitrust enforcement on producer prices in a pooled sample of up to 884 product and service categories for the years 1990 through 2013. Second, a firm-level study will be conducted explaining profit-margins and return on investment; in this study, we attempt to distinguish the effects of antitrust cases against others in the industry

\footnotetext{
${ }^{5}$ Consistent with this is the finding in Feinberg (1984) of price declines post-investigation in $61 \%$ of 23 US industries investigated between 1961 and 1978, but not charged with price-fixing.
} 
from effects against the firm in question. For the first study, the regression specification is a panel data model (using monthly observations):

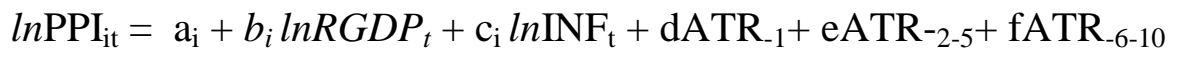

where $\mathrm{PPI}_{\mathrm{it}}$ is the producer price index for product $\mathrm{i}$ in period $\mathrm{t}(\mathrm{indexed}$ at $2010=100$ ) and explanatory variables are macroeconomic variables (an economy-wide price deflator and real GDP) to capture cost and demand pressures, as in Feinberg (1986) -- $\mathrm{INF}_{\mathrm{t}}$ and $\mathrm{RGDP}_{\mathrm{t}}{ }^{6}$-- plus a series of dummy variables representing lagged (both to allow for time for pricing decisions to be made and to deal with possible endogenity of a case filing) antitrust cases (one year, two-tofive year, and six-to-ten year lagged), ATR $_{-1}, \mathrm{ATR}_{-2-5}$, and $\mathrm{ATR}_{-6-10}{ }^{7}$ We allow productspecific fixed effects (which should capture market structure and other product-heterogeneity issues) as well as product-specific responses to cost and demand movements. ${ }^{8}$

The firm-level study explaining profit-margins and return on investment allows us to incorporate both firm and industry-specific antitrust measures to study whether deterrence is achieved by "demonstration" or "neighbor" effects of cases against others in the same industry. Several specifications (and subsamples of the data) are used to test the deterrence effects on firm profitability.

\footnotetext{
${ }^{6}$ As noted below, in place of RGDP we also employ an industrial production (IP) index for Korea.

${ }^{7}$ The dates are of the resolution of a case, not the start of an investigation.

${ }^{8}$ Given the long time series incorporated in our panel, we did the Im-Pesaran-Shin unit-root test for unbalanced panel data. In logs, the null hypotheses that all panels contain unit roots were rejected for all dependent and independent variables.
} 
Given the absence of effects beyond one year in the price index study above, the main specification includes just short and medium "direct effects" (ATR-1 ATR-2-5) as well as "neighbor effects" on the other firms in the same industry $\left(\right.$ NEIATR $_{-1}$, NEIATR-2-5 $_{2}{ }^{9}$

$$
\text { Profitabiltiy }_{\mathrm{ti}}=\mathrm{a}_{\mathrm{i}}+\mathrm{bX}_{\mathrm{it}}+\mathrm{cATR}_{-1}+\mathrm{dATR}_{-2-5}+\text { fNEIATR }_{-1}+\text { gNEIATR-2-5 }_{-5}
$$

where $\mathrm{X}_{\mathrm{it}}$ includes a series of control variables of lesser interest: total assets as a share of sales (TA), advertisement expenditures relative to sales (AD), market share (MS), firm size (SIZE), firm age (AGE). The NEIATR variables are dummy variables taking on a value of 1 if a firm has not been convicted for cartel activities but belongs to an industry where there has been any cartel case in the time period considered. Market share is calculated as the firm's share of sales at the industry level. The variable SIZE takes 1 if a firm is classified as a large firm in terms of the number of employees (more than 300). ${ }^{10}$

\section{Data}

\section{Anti-cartel case records}

We collected and compiled anti-cartel cases obtained from the KFTC. There are 305 cases where 1857 firms are involved from 1994 to 2013 (some of the firms are investigated more than once and double-counted). The KFTC documents provide other details about the case such as duration of collusion, residence, amount of fine (which we may make use of in future extensions of this research). Price-fixing and bid-rigging cases can be separately identified; in

\footnotetext{
${ }^{9}$ When we include a dummy variable for cases between 6 and 10 years ago, results are similar to those presented here.

${ }^{10}$ We also attempted a so-called "pulse effects" analysis, as in Jensen (2007) and Gruber and Hungerman (2008). The short, medium, and long-run effects are separately estimated. Results, not reported here, are quite similar to those from our basic model specification.
} 
preliminary work we could not find differential effects on subsequent pricing behavior, so we combine these for the purposes of this study.

2. PPI and macroeconomic variables

The Bank of Korea compiles a monthly producer price index series which covers 884 items, comprising 801 products and 83 services. In the regression we used the PPI in 288 moreaggregate categories since some of the collusion cases covered two or more items and the share of products with no involvement in cartel cases is too large in the detailed item-level classification.

Two alternate measures, real GDP (RGDP) and the index of industrial production (IP), are used to represent the overall state of the economy. Real GDP covers the entire period of PPI data but it is only available quarterly. Industry production index is provided monthly but only from 2000, therefore we have tried both measures. Inflation (INF) is the rate of change in consumer prices which are compiled by Statistics Korea, the national statistics agency.

\section{Firm profitability and its determinants}

Financial statements of the firms from 1990 to 2012 are obtained from KIS (Korea Information Service) which collects and provides information about companies listed on the Korean Stock Exchange and registered on the KOSDAQ market. Of course, returns calculated

from accounting data are different from economic profits. For robustness we tried three measures 
of firm profitability. Gross profit margin (GPROFIT) is calculated as (sales - cost of sales)/sales. If we assume constant marginal costs or use average variable costs as a proxy for marginal costs, then GPROFIT can be viewed as a proxy for the price-cost margin (or Lerner Index) since sales $=\mathrm{P}^{*} \mathrm{Q}$ and cost of sales $=\mathrm{c}^{*} \mathrm{Q}$. Operating profit margin (OPROFIT), which is the ratio of operating income to sales, and return on assets (ROA), which is the ratio of operating income to total assets, are the other two measures.

The firm level financial data is matched with anti-cartel case records and firm- and industry-level incidence of antitrust cases are constructed. Control variables which may affect the rate of returns are also from the KIS dataset. To control the effects of assets and market power on profitability, total assets to sales ratio (TA) and market share (MS) are included. Advertisement expenditure can also be an important factor for profitability, thus advertising expenditure to sales ratio (AD) is included.

In the financial statement dataset, observations with unreasonable values such as negative sales or total assets were found and dropped. Small amount of sales often created unreasonably large or small values in dependent and independent variables. To check the robustness of our results, we show the results only with observations on which sales are greater than 100 million KRW (approximately \$100,000) along with the results from the whole sample. We also have run 
the same regressions with cutoff sales of $\$ 200,000$ and by deleting upper and lower $5 \%$ tails, but qualitatively same results were obtained. ${ }^{11}$

\section{Estimation Results}

We first estimate equation (1) for the entire sample period (1989 to 2013) (using RGDP as the overall demand proxy) and for the 2000 to 2013 period for which monthly IP data are available. ${ }^{12}$ For both we report results with random product effects, first restricting macroeconomic effects on product prices to be constant across industries and then allowing them to be industry-specific. ${ }^{13}$ These are shown in Tables 3 and 4. In columns (1) and (2) of Table 3 we see no significant impact of antitrust cases on product prices over the full time period, but a 6.3 percent price reduction in the year after a case when the sample starts in 2000 . These results can be explained by the fact that antitrust enforcement has become increasingly stringent in Korea. In terms of pecuniary costs of cartel, the average fines per case from 1996 through 1999 were \$1.3 million while the fines for ten years after 2000 were $\$ 7.5$ million. However, long-term deterrence effects were not found even in the sub-sample in more recent years.

Assuming that all products have the same price responses to economy-wide demand and cost trends is implausible. Therefore, in Table 4, we allow for product-varying impacts of RGDP (and IP) and INF, but the results are quite similar: weak results for the full time period (column

\footnotetext{
${ }^{11}$ The results with subsamples can be provided upon request.

${ }^{12}$ For this latter period results are quite similar whether RGDP or IP are included; we report the results with IP.

${ }^{13} \mathrm{~A}$ Hausman test was performed and no significant difference in coefficients of the fixed-effects and randomeffects models was found.
} 
(1), but a significant one-year effect (here about 3.4\%) since 2000, in column (2). ${ }^{14}$ The finding of no significant long-term impacts of antitrust enforcement is not surprising, consistent with much of the previous literature going back to Feinberg (1984).

Turning now to the firm-level regressions, Table 5 presents results for equation (2) explaining return on assets - including all firms as well as restricting the analysis to firms above $\$ 100,000$ in sales. Of the control variables, we see that higher market shares translate into larger ROA while more advertising-intensive firms have lower ROA (the latter result may be related to consumer vs. producer good differences in profitability). Consistent with the PPI results, we find a short-run negative impact of antitrust cases affecting the particular firm and (somewhat smaller) a short-run negative "neighbor" effect as well. The antitrust effects are larger when all firms are included, suggesting that small firms may be particularly concerned with antitrust investigations affecting them and others in their industry. In columns (3) and (4) we split the sample at 2005, when the leniency program was strengthened, and find larger and more significant direct oneyear effects after 2005. No antitrust impacts are observed in the two-to-five year period following a case.

Tables 6 and 7 present comparable results for the gross profit and operating profit margins, respectively. Again we find a short-term firm-specific negative impact of antitrust and a stronger direct one-year impact is found post-2005 as with ROA. Surprisingly, a positive "neighbor" effect on gross profit margins is found but the effect disappears when the sample is

\footnotetext{
${ }^{14}$ The 288 product-varying coefficients of each of INF and the demand proxies are not reported here.
} 
split into two time periods. It implies that cross-sectional difference in profitability between noncollusive firms in the industries which were recently convicted for cartel and the industries which were not is insignificant. The positive neighbor effect is not found either when the sample is restricted to the firms with sales over $\$ 200,000$ (in results not reported here). ${ }^{15}$

\section{Conclusion}

The results presented here are consistent across two very different data samples for the Korean economy. They are consistent as well with previous work suggesting that long-term deterrence is unlikely to be observed from antitrust investigations, though short-term price (and possibly profit margin) impacts may be expected. However, the stronger effects observed since the more rigorous enforcement of antitrust in Korea over the past decade suggest that firms are beginning to pay careful attention to the actions of the KFTC.

The results are also consistent with the view that the major long-term impact of rigorous enforcement of anti-cartel policy may be an economy-wide regime effect of lower prices resulting from a more competitive environment. These regime effects are difficult to document, requiring the study of a natural experiment with a significant change in enforcement policy or legislation without other confounding events occurring at the same time. Nevertheless, it would be desirable to try and investigate these impacts in future work.

\footnotetext{
${ }^{15}$ We also tried interacting the antitrust variables with a measure of the severity of fines in the case; the interaction terms were not statistically significant and the general pattern of results presented here was unaffected.
} 


\section{References}

Beckenstein, Alan and H. Landis Gabel, "Antitrust Compliance: Results of a Survey of Legal Opinion,” Antitrust Law Journal, Vol. 51, No. 3, 1982, pp. 459-516.

Bergman, Mats A., "Quis Custodiet Ipsos Custodes? Or Measuring and Evaluating the Effectiveness of Competition Enforcement," De Economist, Vol. 156, No. 4, 2008, pp. 387-409.

Besanko, David and Daniel F. Spulber, "Antitrust Enforcement Under Asymmetric Information," The Economic Journal, Vol. 99, No. 396 (June 1989), pp. 408-425.

Block, Michael K., Nold, Frederick C., and J. Gregory Sidak, "The Deterrent Effect of Antitrust Enforcement," Journal of Political Economy, Vol. 89, June 1981, pp. 429-445.

Bolotova, Yulia, John M. Connor and Douglas J. Miller, "The Impact of Collusion on Price Behavior: Empirical Results from Two Recent Cases," International Journal of Industrial Organization, Vol. 26, 2008, pp. 1290-1307.

Brenner, Steffen, "An Empirical Study of the European Corporate Leniency Program," International Journal of Industrial Organization, Vol. 27, No. 6, November 2009, pp. 639-645.

Choi, Yun Jeong, "An Empirical Analysis of the Corporate Leniency Program in Korea: Its Amendments in 2005," The Korean Journal of Economics, Vol. 18, No. 2, Autumn 2011, pp. 255-281.

Clarke, J.L. and Simon J. Evenett, "Deterrent Effects of National Anticartel Laws: Evidence from International Vitamins Cartel," Antitrust Bulletin, Fall 2003, pp. 689-726.

Connor, John M., “Global Antitrust Prosecutions of Modern International Cartels," Journal of Industry, Competition and Trade, Vol. 4, No. 3, 2004, pp. 239-267.

Connor, John M., "Effectiveness of Antitrust Sanctions on Modern International Cartels," Journal of Industry, Competition and Trade, Vol. 6, Nos. 3-4, December 2006, pp. 195-223.

Connor, John M., "Price-fixing Overcharges: Legal and Economic Evidence," in Richard O. Zerbe, John B. Kirkwood (ed.) Research in Law and Economics (Research in Law and Economics, Volume 22), Emerald Group Publishing Limited, 2007, pp.59-153.

Connor, John M., "Global Antitrust Prosecutions of International Cartels: Focus on Asia," Working Paper, American Antitrust Institute, May 2008.

Feinberg, Robert M., "Antitrust Enforcement and Subsequent Price Behavior," Review of Economics and Statistics, Vol. 62, November 1980, pp. 609-612.

Feinberg, Robert M., "Strategic and Deterrent Pricing Responses to Antitrust Investigations," International Journal of Industrial Organization, Vol. 2, March 1984, pp. 75-84. 
Feinberg, Robert M., "The Enforcement and Effects of European Competition Policy: Results of a Survey of Legal Opinion," Journal of Common Market Studies, Vol. 23, June 1985, pp. 373384.

Feinberg, Robert M., "The Effects of European Competition Policy on Pricing and Profit Margins," Kyklos, Vol. 39, No. 2, 1986, pp. 267-287.

Gordon, Fiametta and David Squires, "The Deterrent Effect of UK Competition Enforcement," De Economist, Vol. 156, No. 4, 2008, pp. 411-432.

Gruber, Jonathan and Daniel M. Hungerman, "The Church vs. the Mall: What Happens When Religion Faces Increased Secular Competition? Quarterly Journal of Economics, Vol. 123, No. 2, 2008, pp. 831-862.

Harrington, Joseph E., Jr., "Post-Cartel Pricing During Litigation,” Journal of Industrial Economics, Vol. 52, 2004, pp. 517-533.

Harrington, Joseph E., Jr., "Optimal Cartel Pricing in the Presence of an Antitrust Authority," International Economic Review, Vol. 46, No. 1, February 2005, pp. 145-169.

Harrington, Joseph E., Jr., "Optimal Corporate Leniency Programs," Journal of Industrial Economics, Vol. 56, No. 2, June 2008, pp. 215-246.

Hüschelrath, Kai, Nina Leheyda, and Patrick Beschorner, "The Deterrent Effect of Antitrust Sanctions: Evidence from Switzerland," The Antitrust Bulletin, Vol. 56, No. 2, Summer 2011, pp. 427-459.

Jensen, Robert, “The Digital Provide: Information (Technology), Market Performance, and Welfare in the South Indian Fisheries Sector," Quarterly Journal of Economics, Vol. 122, No. 3, 2007, pp. 879-924.

Jeong, Kap-Young and Robert T. Masson, "Market Structure, Entry, and Performance in Korea," Review of Economics and Statistics, Vol. 72, No. 3, August 1990, pp. 455-462.

Miller, Nathan H., "Strategic Leniency and Cartel Enforcement," American Economic Review, Vol. 99, No. 3, June 2009, pp. 750-768.

Motta, Massimo and Michele Polo, "Leniency Programs and Cartel Prosecution," International Journal of Industrial Organization, Vol. 21, 2003, pp. 347-379.

Petersen, Niels, "Antitrust Law and the Promotion of Democracy and Economic Growth," Journal of Competition Law \& Economics, Vol. 9, No. 3, September 2013, pp. 593-636.

Sabbatini, Pierluigi, "Assessing the Impact of Antitrust Intervention by the Italian Competition Authority," De Economist, Vol. 156, No. 4, 2008, pp. 491-505. 
Sproul, Michael F., “Antitrust and Prices," Journal of Political Economy, Vol. 101, No. 4, August 1993, pp. 741-754.

van Sinderen, Jarig and Ron Kemp, "The Economic Effect of Competition Law Enforcement: the Case of the Netherlands," De Economist, Vol. 156, No. 4, 2008, pp. 365-385.

Werden, Gregory J., "Assessing the Effects of Antitrust Enforcement in the United States," De Economist, Vol. 156, No. 4, 2008, pp. 433-451. 
Table 2. Descriptive Statistics

\begin{tabular}{lrrr}
\hline Variable & No. of Observations & Mean & Std. Dev. \\
\hline PPI & 76,308 & 104.61 & 299.79 \\
Real GDP(RGDP) & 86,112 & $182,745.40$ & $60,876.50$ \\
Industry Production (IP) & 48,096 & 86.38 & 13.70 \\
Inflation(INF) & 86,112 & 79.62 & 16.03 \\
& & & \\
ROA & $1,188,663$ & & 36.97 \\
Gross Profit & $1,072,421$ & 0.09 & 0.44 \\
Operating Profit & $1,189,342$ & 0.21 & 0.82 \\
Total Assets (TA) & $1,189,727$ & 0.01 & 26.06 \\
Ads Expenditure (AD) & 667,900 & 1.63 & 0.08 \\
Market Share (MS) & $1,190,412$ & 0.01 & 0.09 \\
SIZE & $1,190,412$ & 0.02 & 0.21 \\
AGE & $1,154,965$ & 0.05 & 8.10 \\
ATR1 & $1,190,412$ & 9.32 & 0.02 \\
ATR2_5 & $1,190,412$ & 0.00 & 0.04 \\
NEIATR1 & $1,190,412$ & 0.00 & 0.24 \\
NEIATR2_5 & $1,190,412$ & 0.06 & 0.36 \\
\hline Observai2 & 0.16 &
\end{tabular}

Observations with sales less than $\$ 100,000$ are dropped in calculation. 
Table 3. Dependent variable is lnPPI (impacts of RGDP, IP, and INF constant across products)

\begin{tabular}{lcc}
\hline & $(1)$ & $(2)$ \\
VARIABLES & rgdp RE & ip RE \\
\hline \multirow{2}{*}{ lnRGDP } & -0.047 & \\
lnINF & $(0.050)$ & $1.040 * * *$ \\
& $1.012^{* * *}$ & $(0.077)$ \\
ATR1 & $(0.090)$ & $-0.063 * *$ \\
& -0.042 & $(0.026)$ \\
ATR2_5 & $(0.033)$ & -0.025 \\
& 0.027 & $(0.030)$ \\
ATR6_10 & $(0.041)$ & -0.001 \\
& 0.048 & $(0.040)$ \\
lnIP & $(0.049)$ & -0.016 \\
& & $(0.071)$ \\
Constant & 0.510 & -0.114 \\
& $(0.609)$ & $(0.422)$ \\
Observations & 76,308 & 45,456 \\
Number of industries & 288 & 288 \\
\hline
\end{tabular}

Robust standard errors in parentheses

$* * * \mathrm{p}<0.01, * * \mathrm{p}<0.05, * \mathrm{p}<0.1$ 
Table 4. Dependent variable is $\operatorname{lnPPI}$ (product-varying impacts of RGDP, IP, and INF)

\begin{tabular}{lcc}
\hline & $(1)$ & $(2)$ \\
VARIABLES & rgdp RE & ip RE \\
\hline ATR1 & -0.00847 & $-0.0339 * *$ \\
& $(0.0146)$ & $(0.0167)$ \\
ATR2_5 & $0.0459 *$ & -0.0130 \\
& $(0.0269)$ & $(0.0189)$ \\
ATR6_10 & $0.0435 *$ & -0.0249 \\
& $(0.0225)$ & $(0.0248)$ \\
& & \\
Constant & 0.870 & -0.121 \\
& $(0.576)$ & $(0.421)$ \\
Observations & 76,308 & 45,456 \\
Number of gid & 288 & 288 \\
\hline \multicolumn{2}{c}{ Robust standard errors in parentheses. Not reported are product-varying effects of } \\
& RGDP, IP and INF & \\
& $* * * p<0.01, * * \mathrm{p}<0.05, * \mathrm{p}<0.1$ &
\end{tabular}


Table 5. Dependent variable is ROA

\begin{tabular}{|c|c|c|c|c|}
\hline VARIABLES & $\begin{array}{c}(1) \\
\text { Whole sample }\end{array}$ & $\begin{array}{c}(2) \\
\text { Sales }>100 \\
\text { mil. KRW }\end{array}$ & $\begin{array}{c}(3) \\
\text { Sales }>100 \text { mil. } \\
\text { KRW\&year<2005 }\end{array}$ & $\begin{array}{c}(4) \\
\text { Sales>100 mil. } \\
\text { KRW\&year>=2005 }\end{array}$ \\
\hline ATR1 & $\begin{array}{c}-0.00994 * * \\
(0.00438)\end{array}$ & $\begin{array}{c}-0.00824 \\
(0.00427)\end{array}$ & $\begin{array}{c}0.0132 \\
(0.00694)\end{array}$ & $\begin{array}{c}-0.0205 * * * \\
(0.00557)\end{array}$ \\
\hline ATR2_5 & $\begin{array}{l}-0.00266 \\
(0.00306)\end{array}$ & $\begin{array}{c}-0.000193 \\
(0.00295)\end{array}$ & $\begin{array}{c}0.00216 \\
(0.00550)\end{array}$ & $\begin{array}{l}-0.00403 \\
(0.00447)\end{array}$ \\
\hline NEIATR1 & $\begin{array}{c}-0.00322 * * \\
(0.00163)\end{array}$ & $\begin{array}{c}-0.00316^{* * *} \\
(0.00160)\end{array}$ & $\begin{array}{c}-0.0112 * * * * \\
(0.00289)\end{array}$ & $\begin{array}{c}0.00133 \\
(0.00215)\end{array}$ \\
\hline NEIATR2_5 & $\begin{array}{c}0.00100 \\
(0.00167)\end{array}$ & $\begin{array}{c}0.00137 \\
(0.00146)\end{array}$ & $\begin{array}{l}-0.00345 \\
(0.00240)\end{array}$ & $\begin{array}{c}0.00211 \\
(0.00214)\end{array}$ \\
\hline $\mathrm{AD}$ & $\begin{array}{c}-0.0113^{* * * *} \\
(0.00300)\end{array}$ & $\begin{array}{c}-0.121^{* * *} \\
(0.0303)\end{array}$ & $\begin{array}{c}-0.286^{* * * *} \\
(0.0543)\end{array}$ & $\begin{array}{c}-0.0833 * * * \\
(0.0298)\end{array}$ \\
\hline MS & $\begin{array}{l}0.166 * * * \\
(0.00593)\end{array}$ & $\begin{array}{l}0.148 * * * \\
(0.00528)\end{array}$ & $\begin{array}{l}0.131 * * * \\
(0.00653)\end{array}$ & $\begin{array}{c}0.239 * * * \\
(0.0201)\end{array}$ \\
\hline SIZE & $\begin{array}{c}-0.00472 \\
(0.0129)\end{array}$ & $\begin{array}{l}0.000131 \\
(0.0122)\end{array}$ & & $\begin{array}{l}1.70 \mathrm{e}-05 \\
(0.0127)\end{array}$ \\
\hline AGE & $\begin{array}{l}0.000341 \\
(0.00116)\end{array}$ & $\begin{array}{l}0.000397 \\
(0.00114)\end{array}$ & $\begin{array}{c}0.000416 * * * \\
(0.000160)\end{array}$ & $\begin{array}{l}0.000275 \\
(0.00125)\end{array}$ \\
\hline Constant & $\begin{array}{l}0.0432 * * * \\
(0.00617)\end{array}$ & $\begin{array}{c}0.0578 * * * \\
(0.00598)\end{array}$ & $\begin{array}{c}0.0498 * * * \\
(0.00195)\end{array}$ & $\begin{array}{c}0.0477 * * * \\
(0.00928)\end{array}$ \\
\hline $\begin{array}{l}\text { Observations } \\
\text { R-squared }\end{array}$ & $\begin{array}{c}667310 \\
0.602\end{array}$ & $\begin{array}{c}654017 \\
0.619\end{array}$ & $\begin{array}{c}271196 \\
0.560\end{array}$ & $\begin{array}{c}382821 \\
0.680\end{array}$ \\
\hline
\end{tabular}

Robust standard errors in parentheses. Firm fixed-effects and year fixed effects are not reported $* * * \mathrm{p}<0.01, * * \mathrm{p}<0.05$ 
Table 6. Dependent variable is Gross Profit Margin

\begin{tabular}{|c|c|c|c|c|}
\hline VARIABLES & $\begin{array}{c}\text { (1) } \\
\text { Whole sample }\end{array}$ & $\begin{array}{l}\quad(2) \\
\text { Sales }>100 \\
\text { mil. KRW }\end{array}$ & $\begin{array}{c}(3) \\
\text { Sales }>100 \text { mil. } \\
\text { KRW\&year }<2005\end{array}$ & $\begin{array}{c}(4) \\
\text { Sales }>100 \text { mil. } \\
\text { KRW\&year }>=2005\end{array}$ \\
\hline ATR1 & $\begin{array}{l}-0.00527 \\
(0.00466)\end{array}$ & $\begin{array}{c}-0.00807 * * \\
(0.00411)\end{array}$ & $\begin{array}{c}0.0112 \\
(0.00623)\end{array}$ & $\begin{array}{c}-0.0164 * * * \\
(0.00521)\end{array}$ \\
\hline ATR2_5 & $\begin{array}{c}0.00399 \\
(0.00496)\end{array}$ & $\begin{array}{l}0.000877 \\
(0.00373)\end{array}$ & $\begin{array}{l}-0.00189 \\
(0.00518)\end{array}$ & $\begin{array}{c}0.00215 \\
(0.00661)\end{array}$ \\
\hline NEIATR1 & $\begin{array}{c}0.00825 * * \\
(0.00345)\end{array}$ & $\begin{array}{c}0.00377 * * \\
(0.00181)\end{array}$ & $\begin{array}{c}-0.000884 \\
(0.00115)\end{array}$ & $\begin{array}{c}0.00745 \\
(0.00569)\end{array}$ \\
\hline NEIATR2_5 & $\begin{array}{c}0.0121 \\
(0.00859)\end{array}$ & $\begin{array}{c}0.0108 \\
(0.00647)\end{array}$ & $\begin{array}{c}-0.00510 * * * \\
(0.00124)\end{array}$ & $\begin{array}{c}0.0193 \\
(0.0148)\end{array}$ \\
\hline TA & $\begin{array}{c}-0.00140 \\
(0.000811)\end{array}$ & $\begin{array}{l}-0.00157 \\
(0.00173)\end{array}$ & $\begin{array}{l}-0.000779 \\
(0.000455)\end{array}$ & $\begin{array}{l}-0.00162 \\
(0.00198)\end{array}$ \\
\hline $\mathrm{AD}$ & $\begin{array}{c}-0.646^{* * * *} \\
(0.186)\end{array}$ & $\begin{array}{l}-0.748 \\
(0.620)\end{array}$ & $\begin{array}{l}-0.0308 \\
(0.0305)\end{array}$ & $\begin{array}{l}-1.018 \\
(0.958)\end{array}$ \\
\hline MS & $\begin{array}{l}0.00551 \\
(0.0167)\end{array}$ & $\begin{array}{r}-0.00879 \\
(0.0219)\end{array}$ & $\begin{array}{c}0.0255^{* * *} \\
(0.00877)\end{array}$ & $\begin{array}{l}-0.0832 \\
(0.122)\end{array}$ \\
\hline SIZE & $\begin{array}{c}-0.00783 \\
(0.0180)\end{array}$ & $\begin{array}{c}-0.00358 \\
(0.0176)\end{array}$ & & $\begin{array}{l}-0.00837 \\
(0.0180)\end{array}$ \\
\hline AGE & $\begin{array}{c}0.00133 \\
(0.00267)\end{array}$ & $\begin{array}{c}0.00121 \\
(0.00272)\end{array}$ & $\begin{array}{c}3.04 \mathrm{e}-06 \\
(0.000219)\end{array}$ & $\begin{array}{c}0.00139 \\
(0.00303)\end{array}$ \\
\hline Constant & $\begin{array}{c}0.249 * * * \\
(0.0157)\end{array}$ & $\begin{array}{c}0.251 * * * \\
(0.0190)\end{array}$ & $\begin{array}{l}0.216 * * * \\
(0.00280)\end{array}$ & $\begin{array}{c}0.233 * * * \\
(0.0219)\end{array}$ \\
\hline $\begin{array}{l}\text { Observations } \\
\text { R-squared }\end{array}$ & $\begin{array}{c}597197 \\
0.435\end{array}$ & $\begin{array}{c}590733 \\
0.306\end{array}$ & $\begin{array}{c}250337 \\
0.730\end{array}$ & $\begin{array}{c}340396 \\
0.293\end{array}$ \\
\hline
\end{tabular}

Robust standard errors in parentheses. Firm fixed-effects and year fixed effects are not reported $* * * \mathrm{p}<0.01, * * \mathrm{p}<0.05$ 
Table 7. Dependent variable is Operating Profit Margin

\begin{tabular}{|c|c|c|c|c|}
\hline VARIABLES & $\begin{array}{c}\text { (1) } \\
\text { Whole sample }\end{array}$ & $\begin{array}{l}\quad(2) \\
\text { Sales }>100 \\
\text { mil. KRW } \\
\end{array}$ & $\begin{array}{c}(3) \\
\text { Sales }>100 \text { mil. } \\
\text { KRW\&year }<2005\end{array}$ & $\begin{array}{c}(4) \\
\text { Sales }>100 \text { mil. } \\
\text { KRW\&year }>=2005\end{array}$ \\
\hline ATR1 & $\begin{array}{l}0.0574 \\
(0.145)\end{array}$ & $\begin{array}{c}-0.0114 \\
(0.00861)\end{array}$ & $\begin{array}{c}0.0110 \\
(0.00683)\end{array}$ & $\begin{array}{c}-0.0336 * * * \\
(0.0114)\end{array}$ \\
\hline ATR2_5 & $\begin{array}{l}0.0851 \\
(0.144)\end{array}$ & $\begin{array}{c}0.00790 \\
(0.00556)\end{array}$ & $\begin{array}{l}-0.00402 \\
(0.00659)\end{array}$ & $\begin{array}{c}0.00127 \\
(0.00947)\end{array}$ \\
\hline NEIATR1 & $\begin{array}{l}-0.00181 \\
(0.0279)\end{array}$ & $\begin{array}{l}-0.000874 \\
(0.00297)\end{array}$ & $\begin{array}{l}-0.00189 \\
(0.00253)\end{array}$ & $\begin{array}{c}0.0125 \\
(0.00730)\end{array}$ \\
\hline NEIATR2_5 & $\begin{array}{c}0.0139 \\
(0.0308)\end{array}$ & $\begin{array}{l}0.00943 \\
(0.0100)\end{array}$ & $\begin{array}{c}-0.00722 * * \\
(0.00282)\end{array}$ & $\begin{array}{c}0.0308 \\
(0.0210)\end{array}$ \\
\hline TA & $\begin{array}{c}-0.0156 * * * \\
(0.00369)\end{array}$ & $\begin{array}{l}-0.00409 \\
(0.00274)\end{array}$ & $\begin{array}{c}-0.0114 * * * \\
(0.00375)\end{array}$ & $\begin{array}{l}-0.00370 \\
(0.00283)\end{array}$ \\
\hline $\mathrm{AD}$ & $\begin{array}{c}-3.691 * * * \\
(0.689)\end{array}$ & $\begin{array}{c}-3.341 * * * \\
(0.686)\end{array}$ & $\begin{array}{c}-2.624 * * * \\
(0.293)\end{array}$ & $\begin{array}{c}-3.600 * * * \\
(0.980)\end{array}$ \\
\hline MS & $\begin{array}{c}0.856 * * \\
(0.350)\end{array}$ & $\begin{array}{c}0.232 * * * \\
(0.0326)\end{array}$ & $\begin{array}{c}0.201 * * * \\
(0.0282)\end{array}$ & $\begin{array}{l}0.362 * * \\
(0.148)\end{array}$ \\
\hline SIZE & $\begin{array}{c}0.355 \\
(0.261)\end{array}$ & $\begin{array}{c}0.0191 \\
(0.0298)\end{array}$ & & $\begin{array}{c}0.0242 \\
(0.0322)\end{array}$ \\
\hline AGE & $\begin{array}{c}0.00331 \\
(0.00381)\end{array}$ & $\begin{array}{c}0.00276 \\
(0.00274)\end{array}$ & $\begin{array}{c}0.000524 \\
(0.000441)\end{array}$ & $\begin{array}{c}0.00323 \\
(0.00321)\end{array}$ \\
\hline Constant & $\begin{array}{l}-0.0359 \\
(0.0800)\end{array}$ & $\begin{array}{l}0.0488 * * \\
(0.0220)\end{array}$ & $\begin{array}{l}0.0419 * * * \\
(0.00613)\end{array}$ & $\begin{array}{c}0.000952 \\
(0.0237)\end{array}$ \\
\hline $\begin{array}{l}\text { Observations } \\
\text { R-squared }\end{array}$ & $\begin{array}{c}667310 \\
0.632\end{array}$ & $\begin{array}{c}654017 \\
0.476\end{array}$ & $\begin{array}{c}271196 \\
0.561\end{array}$ & $\begin{array}{c}382821 \\
0.489\end{array}$ \\
\hline
\end{tabular}

Robust standard errors in parentheses. Firm fixed-effects and year fixed effects are not reported $* * * \mathrm{p}<0.01, * * \mathrm{p}<0.05$ 